\title{
Judicial Regionalism's Thwarting of UN Security Council Chapter VII Punitive Cosmopolitanism: Measuring the Effects on International Jurisdictional Constitutionalism
}

\author{
By Solon Solomon*
}

Under Chapter VII the UN Security Council has the authority to legally condemn certain behaviors by enacting binding measures on both states and individuals. On an interstate level, the Security Council has instituted international tribunals, and on a personal level, it has imposed sanctions on individuals.

Focusing on Africa and Europe, this Article aspires to demonstrate how regional actors have acted in order to undermine the UN Security Chapter VII punitive cosmopolitanism, either through the institution of regional criminal courts meant to antagonize the International Criminal Court or through judicial decisions that clearly negate the Council's sanctions regime. In order to preserve international punitive cosmopolitanism, the Article will proceed to develop how regional jurisdictional initiatives can be integrated in the general international constitutional order, in both the criminal and the civil/administrative field.

Keywords: UN Security Council, sanctions regime, International Criminal Court, international constitutionalism, European Court of Human Rights

\section{A. Introduction}

The international community has long desired for normative legal cosmopolitanism. After World War II, the international community tended to see the formation of legal rules as the culmination of a process whose cosmopolitan character related to its viewing of human beings as the fundamental units of moral concern and of equal moral worth. Cosmopolitan law came to be viewed as referring to elements of law transcending the claims of national states and seeking to protect basic, commonly shared humanitarian values. ${ }^{1}$ The transnational character of the threats humanity faces creates overlapping communities of fate, ${ }^{2}$ and also dictates a universal legal response, which inevitably renders a cosmopolitan character to international law. ${ }^{3}$ In these realms, the number of states participating and endorsing certain rules became significant for their affirmation of a universal status. For example, regulation of warfare and certain rules of what is permitted in warfare have been deemed customary status through the fact that almost all states are parties to the Geneva Conventions. In human rights law, international treaties and texts ${ }^{4}$ seem to stem from the reality that there are certain basic rights innate in our human nature. ${ }^{5}$ In international criminal law, international law's cosmopolitanism has found expression in the notion of universal jurisdiction and the perception that natural law calls for the criminalization of certain conducts.

\footnotetext{
*King's College London Dickson Poon School of Law. The article is based on a presentation in Cambridge. The author would like to thank Professor Guglielmo Verdirame and Judge Kenneth Keith for their useful comments and remarks.

${ }^{1}$ David Held, Anthony McGrew, David Goldblatt \& Jonathan Perraton, Global Transformations: Politics, Economics and Culture (1999) 70

${ }^{2}$ L Elliott, 'Cosmopolitan Ethics and Militaries as 'Forces for Good' in Forces for Good: Cosmopolitan Militaries in the Twenty-first Century (L Elliot \& G Cheeseman eds., 2004) 17, 18

${ }^{3}$ Cecile Fabre, Cosmopolitanism, Just War Theory and Legitimate Authority, 84:5 Int'I. Aff. (2008) 963,965

${ }^{4}$ Thus the Declaration stipulates that everybody is entitled to the relevant human rights contained herein, without any distinction of any kind. Similar is the wording in the International Covenant on Civil and Political Rights and the International Covenant on Economic, Social and Cultural Rights. On these see Universal Declaration of Human Rights, G.A. Res. 217A (III), U.N. Doc. A/810, art. 2 (1948); International Covenant on Civil and Political Rights, GA Res. 2200 A (XXI), Dec. 16, 1966, art.2; International Covenant on Economic, Social and Cultural Rights, 993 UNTS 3, art. 2

${ }^{5}$ Cecile Fabre, 'Cosmopolitanism, Just War Theory and Legitimate Authority' (2008) 84:5 Int'l. Aff. 963,966
} 
Yet, it is in these same fields that international law's cosmopolitanism efforts have met objections. For example, the laws of war state on a universal basis who may not be killed, but this cosmopolitanism does not equally address the questions of why we kill or who may kill. ${ }^{6}$ More importantly, the perception that the use of force in some cases-such as in humanitarian interventions-can constitute a cosmopolitan, human-equality based answer to injustice overlooks the acts of killings necessitated for its imposition, ${ }^{7}$ as well as the fact that other pragmatic parameters such as interests may play an important role in a state's decision to embark into such an intervention. ${ }^{8}$

In human rights law, many have deplored the universal character of the field as cultural imperialism and an attempt by the West to impose its values. ${ }^{9}$ In international criminal law, some have questioned whether international crimes in fact stem from natural law. ${ }^{10}$

As such, international law's cosmopolitanism is left maim once perceived as just an expansion of common ideas and values. It must relate also to measures-meant to apply and bind citizens irrespective of their national identity-as it has been understood in U.S. scholarship. In the post-9/11 era, American scholars have termed the application of U.S. laws on foreign nationals under U.S. control as legal or judicial cosmopolitanism. ${ }^{11}$

The present Article does not refer to cosmopolitanism from this perspective. Nevertheless, this particular approach - to the extent that it relates to cosmopolitanism not only as a set of common values but also as certain measures-serves as a bridge between the Platonic world of ideas and what I argue to be "punitive cosmopolitanism," namely the attempt of the international community to impose powers, common binding measures, and rules among its members through the Security Council (SC) Chapter VII. Under Chapter VII, the international community does not emphasize common values, but rather common duties. As such, cosmopolitanism does not target the whole social fabric and its underlying ideology, but specific individuals. In that sense, it becomes more focused.

In its discussion on the SC cosmopolitanism, this Article will first examine the modes under which punitive cosmopolitanism is expressed and then analyze the challenges posed to it by regional bodies.

\section{B. The UN SC Punitive Cosmopolitanism}

SC Resolutions passed under Chapter VII are binding on member states. ${ }^{12}$ Parties disagree on whether their binding force means that these Resolutions are automatically incorporated in the domestic sphere, or if they are subject to further legislative initiatives under domestic law. ${ }^{13}$ Irrespective of the positivist approach taken to the

\footnotetext{
${ }^{6}$ Cecile Fabre, Cosmopolitan War (2012) 2

7 Ibid

${ }^{8}$ Ulrich Beck, War is Peace: On Post-National War, (2005) 36 Security Dialogue 5, 15
}

${ }^{9}$ Rebecca J. Cook, State Responsibility for Violations of Women's Human Rights, (1994) 7 Harv. Hum. Rts. J. 125, pincite; Barrett Breitung, Interpretation and Eradication: National and International Responses to Female Circumcision (1996) 10 Emory Int'l. L. Rev. 657, pincite; Reginald Ezetah, The Right to Democracy: A Qualitative Inquiry (1997) 22 Brooklyn J. Int'l. L. 495, 499; Andrew Coleman \& Jackson Maogoto, Democracy's Global Quest: A Noble Crusade Wrapped in Dirty Reality? (2005) 28 Suffolk Trans. L. Rev. 175, 219-220. For a classical approach towards the existence of such right see Thomas M. Franck, The Emerging Right to Democratic Governance (1992) 86 AJIL 46, 49

${ }^{10}$ Win-chiat Lee, 'International Crimes and Universal Jurisdiction' in International Criminal Law and Philosophy (Larry May \& Zachary Hoskins eds., 2010) 15,20

${ }^{11}$ Peyton Cooke, Bringing the Spies in From the Cold: Legal Cosmopolitanism and Intelligence Under the Laws of War (2010) 44 U.S.F. L. Rev. 601, pincite; Eric Posner, 'Boumediene and the Uncertain March of Judicial Cosmopolitanism' (2008) Cato Sup. Ct. Rev. 23, pincite

12 On this see Arts. 24, 25 of the UN Charter; Legal Consequences of the Construction of a Wall in the Palestinian Occupied Territory, ICJ Rep. 2004 136, [it would be helpful to provide what page paragraph 26 is on] para.26. But see also Oberg, poignantly noting on the fact that in its advisory opinion, the International Court of Justice (ICJ) held Israel accountable for contravening a number of Resolutions, none of which though were adopted under Chapter VII, that only obligations can be contravened (without though relating as to whether this should mean that according to the Court Resolutions adopted outside Chapter VII can also have a binding effect.) Marko Divac Oberg, 'The Legal Effects of Resolutions of the UN Security Council and General Assembly in the Jurisprudence of the ICJ' (2005) 16 EJIL $879,885$.

${ }_{13}$ Magdalena M. Martinez, National Sovereignty and International Organizations (1996) 309-311. For a view approaching this debate as similar to the one around the incorporation of international treaties in domestic law see Emilio J. Cardenas \& Mariano Garcia-Rubio, 
specific question of their incorporation, on a pragmatic level, SC Chapter VII Resolutions must be deemed more directly applicable by states in cases that institute mechanisms focusing on individuals. It is much easier politically for a state to comply with an individual-oriented Resolution rather than a Resolution that raises issues regarding the use of force and a state's participation in an armed conflict. In these cases, states opt to stay aside, leaving the enforcement of such Resolutions to states that actually want to engage in military action. ${ }^{14}$

On the other hand, international criminal law's focus on the individual provides an opportunity for tangible legal remedies on moral issues. ${ }^{15}$ The same is true for any punitive apparatus, even in the broad sense, where punishment comes as an administrative preventive measure. In both cases, the SC's cosmopolitanism is not punitive in the sense that it endorses punishment per se, but as a means to safeguard international peace. It aspires to set universal standards meant to be enforced by all UN members on certain individuals who have transgressed. Members could achieve this through actions or moral support of certain precepts that the international community shares, such as the ideal of peace and the notion that all persons are entitled to human dignity. ${ }^{16}$ Accordingly, relevant SC Resolutions work either to punish certain acts post facto through the establishment of international criminal tribunals, or ex ante through the imposition of a sanctions regime against certain individuals who foster and support international crimes.

In the realms of these two pillars, this Article will examine the SC punitive cosmopolitanism's development and consequent restraint by judicial regionalism.

\section{Resolutions Establishing International Criminal Tribunals}

In the nineteenth century, the perception already existed that certain actions constitute international crimes that cannot be left unpunished. ${ }^{17}$ The atrocities of World War II accelerated the development of this thought and intensified the notion that international criminal courts must hold individuals accountable for their conduct. As the International Military Tribunal in Nuremberg put it, "[C]rimes against international law are committed by men, not by abstract entities and only by punishing individuals who commit such crimes can the provisions of international law be enforced." 18 The International Criminal Tribunal at Nuremberg and the International Military Tribunal for the Far East at Tokyo were established on this basis. At the same time, these tribunals rendered the impression that the distribution of justice could be bias-stained once undertaken by the war's victors.

During the decades that followed the culmination of the war, many called for the institution of an international criminal court, but this was not rendered feasible. Yet, towards the end of the twentieth century, the civil war in former Yugoslavia and the atrocities committed obliged the international community to take a stance. At this time, the international community opted for the establishment of an ad hoc international criminal tribunal through an SC Resolution.

Resolution 827 established the International Criminal Tribunal for the Former Yugoslavia (ICTY) in $1993 .{ }^{19}$ It aimed to constitute a universal response to crimes committed throughout the civil war in former Yugoslavia. At the same time, the Tribunal's establishment introduced punitive cosmopolitanism. All states were obligated to

\footnotetext{
'Argentina' in National Implementation of United Nations Sanctions: A Comparative Study (Vera Gowlland-Debas ed., 2004) 81, 83; but see also article 93 of the constitution of the Netherlands (mapping the direct effect of SC Resolutions in the domestic legal order).

${ }^{14}$ Although article 48 of the UN Charter stipulates that the SC can determine that certain states are to undertake action for the maintenance of international peace and security, in practice, the SC does not proceed to such specification.

${ }^{15}$ Yitiha Simbeye, Immunity and International Criminal Law (2004) 66-67

${ }^{16}$ For the connection between the notion of human dignity and crimes against humanity see William Saunders Jr \& Yuri Mantilla, 'Human Dignity Denied: Slavery, Genocide, and Crimes against Humanity in Sudan' (2002) 51 Cath. U. L. Rev. 715, pincite.

17 Ilias Bantekas \& Susan Nash, International Criminal Law (3 ${ }^{\text {rd }}$ ed., 2007) 5 (referring inter alia to piracy and war crimes.)

18 Judgment of the International Military Tribunal for the Trial of German War Criminals 41 (Nuremberg, 30th September and 1st October, 1946)

19 UN SC Res. 827 (1993)
} 
refer individuals accused of these acts to the same Tribunal, punishable by the Tribunal's Statute binding all UN members.

The format chosen for the creation of the ICTY has been repeated in the creation of the other ad hoc tribunals that followed. In all of these cases, the international community resorted to the SC Resolution module to shelter these tribunals from accusations of expressing states' parochial interests. Further, this forum aimed to bind the vast majority of the international community on certain crimes that states agree should be prosecuted and punished on an international judicial level. Yet, at the same time, some states felt that these Resolutions, carrying a normative load, namely a Statute, not embalmed in the Resolutions' text but equally binding UN members, could not be treated the same way that the other Chapter VII Resolutions and their incorporation in domestic law had to follow a more active paradigm. Thus, though Denmark had in force a general Act permitting incorporation of Resolutions in domestic law, it was also required to enact a specific law in order to implement Resolution $827 .{ }^{20}$

The process of the Security Council's punitive cosmopolitanism culminated with the creation of the International Criminal Court (ICC). The Court was meant to be a universal mechanism enhancing accountability for behaviors equally condemned by the international community, or in the words of then UN Secretary-General Kofi Anan, "[A] giant step forward in the march towards universal human rights and the rule of law." ${ }^{21}$

Though a product of a multilateral treaty, the Rome Statute, and from a Resolution, the ICC should nevertheless be viewed as the direct and natural product of the SC tribunals' creation. Albeit, the ICC expresses punitive cosmopolitanism through its rendering of the Rome Statute in Article 17 by including the right of the SC to refer a case or a situation to the Court. This inclusion resulted from compromises in favor of territorial and national concerns regarding jurisdiction. Yet, the notion that states cannot be bound by documents that indirectly refer to SC Resolutions found its place regarding the ICC's Statute and the question whether states non signatories to the Rome Statute, should hand down individuals under prosecution to the ICC. The Gaddafi and Bashir cases palpably portrayed this issue.

Echoing the rhetoric on the post World War II military tribunals, the ICC has been exposed to criticism of bias. In this case, parties have not perceived the Court as serving the interests of the victors, but those of western powers. Along these lines, the punitive cosmopolitanism, built so tenuously for years by the SC, seems to be thawing. Yet, while it is logical for dialogue among legal institutions to take place on political grounds in a highly politicized international community, punitive cosmopolitanism is doubted once its entire rhetoric takes the form of the introduction of other regional judicial schemes. This Article will evaluate this in relation to the establishment of regional criminal tribunals in the next sections. First, however, the Article analyses the other mechanism of SC punitive cosmopolitanism - the Resolutions endorsing individual sanctions.

\section{Resolutions Endorsing Individual Sanctions}

In 1999 SC Resolution 1267 established a sanctions committee meant to list individuals who posed a threat to global peace and security and accordingly restrain their freedom of movement or the free enjoyment of their assets. ${ }^{22}$ Followed by a series of Resolutions reaffirming the sanctions committee in the aftermath of the 9/11 attacks, ${ }^{23}$ and realizing the difficulty of proving their link to the attacks, the adoption of the sanctions regime gave the international community the ability to include individuals who could not be accused and tried for a specific attack in its punitive measures. This allowed the international community to punish and restrict the movement of individuals generally involved in terrorism. In that sense, the SC endorsed the view that terrorism

\footnotetext{
${ }^{20}$ Frederik Harhoff, 'Denmark' in The Integration of International and European Community Law into the National Legal Order: Study of the Practice in Europe (Pierre M Eisemann, ed., 1996) 168-69

${ }^{21}$ U.N. Secretary-General, Statement by the United Nations Secretary-General Kofi Annan at the Ceremony Held at Campidoglio Celebrating the Adoption of the Statute of the International Criminal Court, Jul. 18, 1998 available at http://www.un.org/icc/speeches/718sg.htm [this link does not work; please provide a different address].

${ }^{22}$ SC Res. 1267 (Oct. 15, 1999)

${ }^{23}$ SC Res. 1333 (Dec. 19, 2000); SC Res. 1390 (Jan. 28, 2002); SC Res. 1455 (Jan, 17, 2003); SC Res. 1526 (Jan. 30, 2004 ); SC Res. 1617 (Jul. 29 , 2005); SC Res. 1735 (Dec. 22, 2006); SC Res. 1822 (Jun. 30, 2008) and SC Res. 1904 (Dec. 17, 2009)
} 
is not strictly confined to the actual actions, but also includes ideological and moral support for such actions that cannot remain legally indifferent as far as its prosecution is concerned. ${ }^{24}$

All UN members are expected to enforce these Resolutions, leading to a universal, cosmopolitan punitive stance against certain individuals. Yet, the fact that the Resolutions did not also establish an independent judicial mechanism where persons harmed by these sanctions could resort to protection ${ }^{25}$ left punitive universalism uncovered. Judicial regionalism filled this judicial gap.

Thus, in cases like Kadi and Bosphorus, European regional courts held that states were accountable for the implementation of $\mathrm{SC}$ sanctions-introducing Resolutions. ${ }^{26}$ This judicial pronouncement opened Pandora's Box, rendering the sense that ultimately, the absolute punitive cosmopolitanism introduced by these Resolutions can be judged by judicial regionalism. The legal dangers that remain will be examined through the analysis of the $A l-$ Dulimi case.

\section{Judicial Regionalism and the Thwarting of SC Punitive Cosmopolitanism}

\section{Judicial Criminal Regionalism}

The African continent initially embraced the International Criminal Court. ${ }^{27}$ Yet, gradually, while this enthusiasm did not entirely subside, ${ }^{28}$ African states began to view the Court with increased suspicion. The fact that the Court tended to focus on crimes committed in Africa led to the perceptions that the Court was merely a Western entity meant to serve a colonialist Western dominance over Africa and that justice had become politicized. ${ }^{29}$

This concern was heavily stressed once ICC indictments focused on sitting heads of African states that were not members of the Courts, such as Sudan and Libya. A debate erupted concerning whether leaders of these two countries were protected by immunity or could be extradited to The Hague based on the universal character of relevant Security Council Resolutions. ${ }^{30}$ This contention should be perceived as touching the core of the cosmopolitanism-regionalism nexus.

\footnotetext{
${ }^{24}$ In that sense, this approach is similar to that endorsed by Israel's Supreme Court regarding the issue of direct participation of civilians in hostilities. On this see Public Committee against Torture v. Israel, H.C. 5100/94 (Israel 1999), [provide page if possible] para.37 (noting that moral support of terrorism can also lead to the negation of civilian status.)

${ }^{25}$ Dire Tladi \& Gillian Taylor, 'On the Al-Qaida/Taliban Sanctions Regime: Due Process and Sunsetting' (2011) 10 Chinese J. Int'l. L. 711, pincite.

${ }^{26}$ For a brief but concise history of the Kadi case before the European Court of Justice see Erika de Wet, From Kadi to Nada: Judicial Techniques Favouring Human Rights over United Nations Security Council Sanctions, 12 Chinese J. Int'I. L. 787, 790-92 (2013); Frank Schorkopf, 'The European Court of Human Rights' Judgment in the case of Bosphorus Hava Yollari Turizm v. Ireland' (2005) 6 German L. J. 1255 , pincite.

${ }^{27}$ Charles Chernor Jalloh, Africa and the International Criminal Court: Collision Course or Cooperation? 34 N.C. Cent. L. Rev. 203, 204-6 (2012); Max du Plessis, The International Criminal Court that Africa Wants, Monograph No. 172 (2010) 5-6 available at http://www.issafrica.org/uploads/Mono172.pdf
}

${ }^{28}$ African states actively participated in the ICC Review Conference in 2010, following also a similar call by the AU for its Members to do so. On this see Max du Plessis, The International Criminal Court that Africa Wants, Monograph No. 172 (2010) 3 available at http://www.issafrica.org/uploads/Mono172.pdf

${ }^{29}$ Charles Chernor Jalloh, 'Africa and the International Criminal Court: Collision Course or Cooperation?' (2012) 34 N.C. Cent. L. Rev. 203, 209-10. But see also Max du Plessis, The International Criminal Court that Africa Wants, Monograph No. 172 (2010) 19-24 available at http://www.issafrica.org/uploads/Mono172.pdf ; Eugene Kontorovich, Africa's Undermining of the International Criminal Court, Georgetown J. Int'l. Aff. Oct. 29, 2013 available at http://journal.georgetown.edu/2013/10/29/africas-undermining-of-the-internationalcriminal-court-by-eugene-kontorovich/ (discussing also why notions of ICC's prejudice towards Africa should be dismissed.)

\footnotetext{
${ }^{30}$ Dapo Akande, The Bashir Indictment: Are Serving Heads of State Immune from ICC Prosecution, Oxford Transitional Justice Research Working Paper Series 87 (2008), available at http://www.fljs.org/uploads/documents/Justice in Africa.pdf [this link does not work; please provide a new address]; see also Dapo Akande, 'The Legal Nature of Security Council Referrals to the ICC and its Impact on Al Bashir's Immunities' (2009) 7 JICJ 333, pincite (2009); Paola Gaeta, 'Does President Al Bashir Enjoy Immunity from Arrest?' (2009) 7 JICJ 315, pincite; C Jalloh, Regionalizing Criminal Law? (2009) 9 Int'I Crim. L. Rev. 445, 484
} 
Following the ICC's Prosecutor's issuance of an arrest warrant for Sudan's Bashir, the African Union (AU) repeatedly called on the UNSC to defer the ICC process pursuant to Article 16 of the Rome Statute. ${ }^{31}$ Moreover, the $\mathrm{AU}$ gained the support of other regional bodies such as the Arab League and the Organization of Islamic Conference. ${ }^{32}$ Due to this alignment, any opposition to punitive cosmopolitanism was rendered a keen regional color. Once African hopes for a UNSC deferral did not come into fruition, the African regionalism towards the Court also acquired judicial elements. In 2009 at the Assembly of Heads of States, African leaders decided that AU member states should refuse to cooperate with the ICC and should not enforce the Bashir arrest warrant. ${ }^{33}$ Subsequent AU summits reiterated this decision. ${ }^{34}$ As such, it denotes an important stance of a regional body such as the AU towards punitive cosmopolitanism. The practical implications of this stance became evident when once the AU explicitly held that Chad's decision to allow a Bashir visit should not be penalized. ${ }^{35}$

This political endorsement of regionalism in international criminal matters quickly undertook quasi-judicial and judicial facets. Thus, the AU adopted a High-Level Panel under former South African President Thabo Mbeki to examine how the issues of accountability and combating impunity on one hand, and reconciliation and healing on the other hand, could be effectively and comprehensively addressed in Darfur. ${ }^{36}$ In 2009, the Panel submitted its Report, recommending the creation of a hybrid court for Darfur. ${ }^{37}$ Moreover, in a number of decisions, the AU highly encouraged the process of expanding the mandate of the African Court on Human and Peoples' Rights to also include the prosecution of international crimes. ${ }^{38}$

Ideas of creating such a Criminal Chamber originated in 2007-08 when the Group of African Experts established by the AU in order to consider a possible merger between the African Court on Human and Peoples' Rights with the African Court of Justice recommended the expansion of the Court's jurisdiction to criminal matters. ${ }^{39}$ While these suggestions did not proceed at that time, they were brought to the forefront once again following the debate regarding the ICC's jurisdiction over sitting African leaders, as well as in light of the indictments brought in Europe against African officials. ${ }^{40}$ In 2012, the Meeting of the Ministers of Justice and/or Attorneys General ${ }^{31}$ AU Peace and Security Council, Communique of the 142nd Meeting of the Peace and Security Council, PP 3, 5, 9, 11(i), PSC/MIN/Comm.
(CXLII) (July 21, 2008); AU Assembly, Decision on the Application by the International Criminal Court (ICC) Prosecutor for the Indictment of
the President of the Republic of the Sudan, PP 2, 3, Assembly/AU/Dec.221 (XII) (Feb 3, 2009); AU Peace and Security Council, Communique
of the 175th Meeting of the Peace and Security Council,, PP 4-6, PSC/PR/Comm. (CLXXV)(Mar. 5, 2009). See also Annalisa Ciampi, The
Proceedings Against President Al Bashir and the Prospects of their Suspension Under Article 16 ICC Statute, 6 J. Int'I Crim. Just. 885 , pincite
(2008)

${ }^{32}$ Arab Leaders Back "Wanted" Bashir, BBC News (Mar. 30, 2009), http://news.bbc.co.uk/2/hi/7971624.stm; OIC Secretary General Strongly Rejects the ICC Indictment Against Sudan's President, Newsletter (Organisation of Islamic Cooperation), Mar. 4, 2009, http://www.oic-oci. org/newsletter print.asp?n id=150 [this link does not work; please provide a new address].

${ }_{33} \mathrm{AU}$ Assembly, Decision of the Meeting of African States Parties to the Rome Statute of the International Criminal Court (ICC), Assembly/AU/Dec.245 (XIII), at 2, P10, Doc. Assembly/AU/13 (XIII) July 3, 2009 13th Ordinary Session of the Assembly in Sirte

${ }^{34} \mathrm{AU}$ Assembly, Decision on the Progress Report of the Commission on the Implementation of Decision Assembly/AU/Dec.270(XIV) on the Second Ministerial Meeting on the Rome Statute of the International Criminal Court (ICC), Assembly/AU/Dec.296(XV), at 1, P 5, Doc. Assembly/AU/10(XV) (July 27, 2010, 15th Ordinary Session of the Assembly in Kampala).

35 Decision on International Jurisdiction, Justice and the International Criminal Court (ICC), Doc. Assembly/AU/13(XXI), Assembly/AU/Dec.482(XXI), para.3 (May 26-27, 2013).

${ }^{36}$ African Union High-Level Panel of Darfur, Darfur: The Quest for Peace, Justice and Reconciliation, PSC/AHG/2(CCVII), at i, (Oct. 29, 2009), available at http://www.darfurpanel. org/resources/AUPD+Report+on+Darfur+\$28Eng+\$29+October+26+09.pdf. [this link does not work; please provide a different one]

37 Ibid.

38 Decision on the Implementation of the Assembly Decision on the Abuse of the Principle of Universal Jurisdiction, Doc. Assembly/AU/3 (XII), Assembly of the African Union, $12^{\text {th }}$ Sess., 1-3 Feb. 2009, Addis Ababa, Decision No. 213, para.9; Extraordinary Session of the Assembly of the African Union, 12 October 2013, Addis Ababa, Ethiopia, Decisions and Declarations, Ext/Assembly/AU/Dec.1 (Oct.2013), para.10; Decision on the Progress Report of the Commission on the Implementation of the Decisions on the International Criminal Court, Doc. Assembly/AU/13 (XXII), para.13 (Jan. 30-31, 2014).

39 Don Deya, Is the African Court Worth the Wait?, March 6, 2012, Open Society Initiative for Southern Africa available at http://www.osisa.org/openspace/regional/african-court-worth-wait

${ }^{40}$ Chacha Bhoke Murungu, 'Towards a Criminal Chamber in the African Court of Justice and Human Rights' (2011) 9 J. Int'l. Crim. Justice 1067, 1069-79; Analysis: How Close is an International Criminal Court? IRIN, June 13,2012 available at 
of the AU Member States led to the adoption of a draft protocol on amendments to the Protocol on the Statute of the African Court of Justice and Human Rights. ${ }^{41}$

While jurisdiction in the Court's Statute was originally drafted along the lines of jurisdiction in the ICJ Statute, ${ }^{42}$ the proposed amendments clearly brought about a shift by also endorsing international criminal jurisdiction, completely disregarding the structural hurdles posed for punitive cosmopolitanism. ${ }^{43}$ These hurdles will be further elaborated in the next sections. Such hurdles became more acute once judicial regionalism entered, even on a micro-level. Thus, in December 2013, the East African Council Heads of States voted for the extension of the jurisdiction of the East African Court of Justice to also include international crimes. ${ }^{44}$

\section{Judicial Human Rights Regionalism}

In November 2013, the ECHR rendered its judgment in the Al-Dulimi case, currently pending adjudication before the ECHR Grand Chamber. ${ }^{45}$ The case concerned the implementation of UN Security Council Resolution 1483 by Switzerland, which ordained the freezing of assets of Saddam Hussein and other high officials of Saddam Hussein's regime. In April 2004, the firm Montana Management and its director Al-Dulimi were included in the list of sanctions. In order to implement the Resolution, Switzerland initiated confiscation proceedings against the assets of Al-Dulimi, as well as those of the company.

Al-Dulimi appealed in vain to the sanctions committee in order to be struck from the list. His attempts through the Swiss domestic judicial system were also unsuccessful. ${ }^{46}$ The Swiss Federal Court held that Switzerland was bound by UN Security Council Resolutions, which due to Article 103 of the UN Charter, enjoyed normative priority over Swiss domestic law. Because Resolution 1483 contained a strict obligation, and the right to access an impartial judicial body is not a jus cogens rule, the Swiss court held that it could not review the procedure or substantance of Al-Dulimi's claim. Moreover, because Switzerland could not independently proceed regarding Al-Dulimi's exclusion from the list, the country did not violate either the Swiss constitution or Articles 6 and 13 of the European Convention on Human Rights. Along these lines, the ECHR, holding otherwise, found that Switzerland had indeed violated Article 6 of the Convention. ${ }^{47}$

The particular conclusion of the ECHR touches the core of the tension between universalism and regionalism, as well as the question of whether efforts of homogenous rules through punitive cosmopolitanism should be encouraged or undermined. One could plausibly argue that the Strasbourg court never aimed to undermine punitive cosmopolitanism, but to avoid a situation where UN Security Council Resolutions would be left with no judicial review, especially in cases where individual rights are in peril. ${ }^{48}$

http://www.irinnews.org/report/95633/analysis-how-close-is-an-african-criminal-court; Max du Plessis, The International Criminal Court that Africa Wants, Monograph No. 172 (2010) 2 available at http://www.issafrica.org/uploads/Mono172.pdf

${ }^{41}$ The Report, the Legal Instruments and Recommendations of the Ministers of Justice/Attorneys General, African Union, Executive Council, $21^{\text {st }}$ Ordinary Sess. July 9-13 2012, Addis Ababa, EX.CL/731 (XXI)

42 On this see art. 28 of the Protocol on the Statute of the African Court of Justice and Human Rights, available at http://www.au.int/en/sites/default/files/PROTOCOL_STATUTE_AFRICAN_COURT_JUSTICE_AND_HUMAN_RIGHTS.pdf

\footnotetext{
${ }^{43}$ Draft Protocol on Amendments to the Protocol on the Statute of the African Court of Justice and Human and Peoples' Rights, Meeting of Government Experts and Ministers of Justice /Attorneys General on Legal Matters, May 7-11 and 14-15 2012, Addis Ababa, Exp/Min/IV/Rev.7, p.p.3,13, arts.1,28A [This source is difficult to locate. Consider adding a hyperlink.]

44 Christabel Ligami, EACJ to Handle Criminal Offences, The East African, Dec. 7, 2013 available at http://www.theeastafrican.co.ke/news/EACJ-to-handle-criminal-offences/-/2558/2103006/-/bkbsq5/-/index.html

${ }^{45}$ Al-Dulimi and Montana Management Inc. v. Switzerland, App. No. 5809/08, Judgment, Nov. 26, 2013

${ }^{46}$ Swiss Federal Tribunal, BGE 2A.783/2006, BGE 2A.784/2006, BGE 2A.785/2006, Jan. 23, 2008 [please provide additional information if possible].

${ }^{47}$ Al Dulimi, para.135

48 On this account, see the whole discussion on the equivalent protection criterion doctrine, developed by the Court's jurisprudence and cited also in Al Dulimi, ibid, para. 115
} 
Nevertheless, while judicial review should take place in all cases, questions remain concerning the extent of this review and its limits once the object of the review is no longer the implementation measures of an SC Resolution, but the Resolution itself. While the majority in Al-Dulimi seems to bypass the problem by stating that the Swiss Court should be held accountable for refusing to examine the merits of the case, as if it had such discretion, ${ }^{49}$ the Court's minority opinion poignantly notes the problematic nature of the domestic court in a situation where

... a conflict between obligations under the United Nations Charter and under the Convention could only be solved by giving one of them priority. With sole reference to the "equal protection" principle-which was not applied or even mentioned by the Grand Chamber in Al-Jedda and Nadathe majority have not directly addressed the issue of how such a conflict should be resolved but have only indirectly concluded that, where no equal protection exists, the Convention obligations prevail. ${ }^{50}$

In other words, if the ECHR judgment is enforced in the Al-Dulimi case, the SC Resolution cannot be implemented. Punitive cosmopolitanism is rendered without teeth.

\section{The Importance of Punitive Cosmopolitanism in the Realms of International Jurisdictional Constitutionalism}

One may not find merit in the aforementioned description of how judicial regionalism undermines punitive cosmopolitanism. After all, how would international law as a discipline, and international order and legality in extension, be harmed if judicial regional bodies thwart punitive cosmopolitanism's universal expansion? One could even argue that-similar to the debate surrounding the application of human rights-any victory of regionalism over attempts to impose universal standards despite local and regional differences among the planet's continents.

Yet, there is a significant difference between the global imposition of human rights and punitive cosmopolitanism. As previously noted, the first relates to values, while the second relates to duties. Punishment, as a measure in the legal denouncement of certain behaviors, is included among these duties that the international community can impose. As such, it can take on a universal character.

This Article will first deal with ways in which punitive cosmopolitanism can be realized in the existing legal framework. Still, confined to this level, the analysis is left without a comprehensive, holistic structure. The Article achieves the framework through an extension of the discussion on a de lege ferenda basis. Finally, the last section of the Article will argue that judicial regionalism can adopt a bridging role between the existing legal landscape and its desired reformulation by creatively adapting to the various jurisprudential exigencies.

\section{Infra Legem Punitive Cosmopolitanism}

While a liberal interpretation of the Rome Statute could indeed view regional courts as taking on the role of national judicial bodies for the purposes of complementarity, ${ }^{51}$ such a restructuring of the international criminal jurisdictional model would likely require an explicit confirmation through renegotiation of the Rome Treaty. It is dubious whether that would be possible.

Moreover, if that scheme was adopted for Africa, it would have to be adopted for the other continents as well. The ICC was instituted to constitute a permanent mechanism of international crimes attribution and punishment. As such, any arrangements it endorses must necessarily have a long-term basis and planning. The fact that, currently, people from Africa are the most prosecuted by the ICC does not mean that this will always be the case. The ICC cannot endorse the creation of an African Criminal Court because exigencies seemingly require it now, but rather must expand its vision to the future and also to other continents. Yet, it it is not at all

\footnotetext{
${ }^{49}$ Al Dulimi, para.120

${ }^{50}$ Al Dulimi, Dissenting Opinion of Judge Lorenzen joined by Judges Raimondi and Jociene

${ }^{51}$ C B Murungu, 'Towards a Criminal Chamber in the African Court of Justice and Human Rights' (2011) 9 JICJ 1067, 1081
} 
certain whether states in other continents would agree to form such regional criminal courts. This is particularly true in light of the fact that in two of these continents-the Americas and Asia-there exist powerful states like the U.S., China and Russia, none of which are ICC members. It is difficult to see how these states would acquiesce to the establishment of regional criminal courts.

Judicial regionalism can play a constructive role only by further empowering the SC's punitive cosmopolitanism. While there may have been defects in ICC prosecutions and decisions, the solution is not to undermine the ICC, but rather to strengthen it through constructive criticism and engagement. In some cases, this may mean penalizing conduct that the ICC has opted to leave outside its realms. The approach of the Draft Protocol on the Statute of the African Court of Justice and Human Rights, which penalizes corporate liability in an era when corporations have been accused of grave breaches of international humanitarian law, has been interesting. ${ }^{52}$

The same is true with the tensions the Al-Dulimi case brought to the surface. A situation in which SC Resolutions fall outside the judicial or quasi-judicial review is inconceivable, but these organs have to be either international or domestic. Once focus is on the norm itself and not on its implementation, judicial review can be undertaken only by judicial bodies that share an equal status with the norm's legislating background. Consequently, in judicial regionalism, this parity between the normative source and the essence of the reviewing body is distracted. Regionally-constrained judicial bodies cannot upkeep or annul an international, universal norm, even if this norm has been later incorporated in domestic law.

Regional courts can review only the judicial or legislative acts that constitute a state initiative imposed by a certain state's bilateral or multilateral agreements. Such would be the case with the binding force of SC Resolutions. Norms stemming from SC pronouncements continue to hold substantially to their international status. They do not need to come from a state's legislative initiative in order for these state standards to be subsequently reviewed by regional bodies. Nevertheless, states can develop autonomous initiatives on the way these norms are to be incorporated in the domestic sphere. To the extent these initiatives constitute original conception schemes of the state, they can also be judicially reviewed by regional bodies, as the ECHR and ECJ jurisprudence demonstrates. In these cases, it is the state's maneuvers in the exercise of its discretionary powers that are put under judicial scrutiny.

Regional judicial bodies are not meant to replace state review mechanisms, but rather come post factum to ascertain whether this function has been satisfactory or not. They have a supervisory role over domestic jurisdictions, both on a procedural and substantial law level. By approving through international agreements the subduing of their scrutiny, states have not instituted an additional level of domestic judicial review, but a supervisory mechanism for their conduct. This is the reason why regional judicial bodies cannot annul a domestic decision or norm, but can only award damages to the individuals harmed by the specific domestic judicial or normative arrangement.

Domestic courts are also limited in their judicial review. While they can exercise judicial review, ${ }^{53}$ such a review takes place along the axiom that the SC controls as the primary guardian of international peace and security. ${ }^{54}$ In that sense, domestic courts do not add much to the debate on the norm's international status. ${ }^{55}$

Against this background, stress for the review of the sanctions lists endorsed by punitive cosmopolitanism is put to the institution of the ombudsperson established by Resolution 1904. Yet, the ombudsperson does not cover all sanction regimes imposed by the various Resolutions. Additionally, he or she can make recommendations for

\footnotetext{
${ }^{52}$ Article $46 \mathrm{C}$ of the Draft Protocol. Judicial regionalism's initiatives may ultimately lead though to the penal suppression of the expression of democratic rights and the abuse of the citizens' democratic right to agitate for constitutional reform. On this see the case of the institution of the crime of the 'unconstitutional change of government' in Africa and the International Criminal Court: Mending Fences, Avocats Sans Frontiers, July 2012, p.15 available at http://www.asf.be/wp-content/uploads/2012/08/ASF_UG_Africa-and-the-ICC.pdf

${ }^{53}$ Her Majesty's Treasury (Respondent) v Ahmed (FC), Her Majesty's Treasury v al-Ghabra (FC), R (on the application of Hani El Sayed Sabaei Youssef) v Her Majesty's Treasury, Judgment [2010] UKSC 2; A Tzanakopoulos, 'U.N. Sanctions in Domestic Courts: From Interpretation to Defiance in Abdelrazik v. Canada' (2010) 8 JICJ. 249

${ }^{54}$ D Hovell, 'A Dialogue Model: The Role of the Domestic Judge in Security Council Decision-Making' (2013) 26 Leiden J. Int'l. L. 579,581

${ }^{55}$ A Tzanakopoulos, Collective Security and Human Rights in Hierarchy in International Law: The Place of Human Rights (E. De Wet \& J. Vidmar eds., 2012) 67
} 
the de-listing of an individual, but the final decision lies with the UNSC on a highly political basis. ${ }^{56}$ Despite being reformed, ${ }^{57}$ the institution of the ombudsperson is currently far from functioning even as a quasi-judicial body for the sanctions regime's impartial review.

The second channel through which cosmopolitanism can offer a judicial review for its dicta is directly through recourse to the ICJ. The ICJ has explicitly stated that it has no power to review SC Resolutions, but that it can interpret and apply them. ${ }^{58}$ In essence, the Court's rhetoric resembles that of the domestic and regional jurisprudence in the cases of judicial review of UN individual sanctions. This fact, coupled with the growing tension among international scholars for such a review to be established, ${ }^{59}$ can also claim de lege ferenda the configuration of a new international norm. ${ }^{60}$ With these Resolutions being perceived mutatis mutandis as administrative decisions, ${ }^{61}$ it can be argued that as the latter are reviewed by supreme domestic courts, SC Resolutions can undergo such a judicial process before the ICJ.

While these approaches can hermeneutically take place in the realms of the current international legal regime, they do not provide a response to the comprehensive issue the minority opinion in Al Dulimi posed regarding the relationship between punitive cosmopolitanism and judicial regionalism. In order for this question to be adequately addressed, someone has to envision the international legal order as a constitution, where international law's various fields constitute the various provisions and where harmonization between them is achieved through recourse to the right to dignity. ${ }^{62}$ At the same time, it is the inherent limits of international law that serve as constraints to the attempts of one international field to trump over the other. ${ }^{63}$

This international constitutional model would not be complete absent any procedural aspects regarding how justice is administered in the realms of the international community. The judicial authority is a basic pillar in every polity. Domestic constitutions have provisions relating to the structure of the courts. ${ }^{64}$ In the international field, what is being asked for is the incorporation of the relationship between the different international courts and tribunals, as well as their domestic counterparts in the international constitutional scheme. ${ }^{65}$ Normative hierarchy must be followed by jurisdictional hierarchy.

\section{Praeter Legem Punitive Cosmopolitanism}

\footnotetext{
${ }^{56}$ E de Wet, 'From Kadi to Nada: Judicial Techniques Favouring Human Rights over United Nations Security Council Sanctions' (2013) 12 Chinese J. Int'l. L. 787, 789

57 Ibid., p.p. 789-790

${ }^{58}$ Legal Consequences for States of the Continued Presence of South Africa in Namibia (SouthWest Africa) notwithstanding Security Council Resolution 276 (1970) Advisory Opinion of 21 June 1971, ICJ Reports (1971) 16, at 45, paras.89, 109-110, 115; Accordance with International Law of the Unilateral Declaration of Independence in Respect of Kosovo, Advisory Opinion, ICJ Rep. 2010403, para.85
}

${ }^{59}$ For a list of scholars arguing for such judicial review powers see M Shaw, International Law (6 ${ }^{\text {th }}$ ed., 2008$) 1268$,n.316 ; contra A Aust, Handbook of International Law, ( ${ }^{\text {nd }}$ ed., 2010) 424. For a limited scope of this review see E de Wet, 'The Constitutionalization of Public International Law' in The Oxford Handbook of Comparative Constitutional Law, M Rosenfeld \& A Sajo (eds.,2012) 1221

${ }^{60}$ On this, see article 38 of the ICJ Statute (stating that judicial decisions and the teachings of the most highly qualified publicists of the various nations are subsidiary means for the determination of rules of law).

${ }^{61}$ For the fact that sanctions adopted through SC Resolutions against individuals constitute administrative measures see Human Rights Committee, Sayadi v. Belgium, CCPR/C/94/D/1472/2006 (Dec. 29, 2008), para. 10.11

62 S Solomon, 'The Dynamic Law of Occupation: Inaugurating International Thematic Constitutionalism' (2012) 54 Harvard Int'l. L. Journal Online 59 [add pincite]

63 S Solomon, 'The Quest for Self-Determination: Defining International Law's Inherent Inter-State Limits' (2013) 11 Santa Clara J. Int'I. L. 397 [add pincite]

${ }^{64}$ In common law jurisdictions, see for example article 3 of the US Constitution, chapter 7 of the South African Constitution, chapter III of the Commonwealth of Australia Constitution Act. In civil law jurisdictions, see arts. $147 \& 160$ of the Belgian constitution, art. 117 of the Spanish constitution, section $\mathrm{V}$ of the Greek constitution.

65 P Webb, International Judicial Fragmentation and Integration (2013) 5 
The UN Charter awards hierarchical value to the ICJ, ${ }^{66}$ but domestic legal models provide the answer as to how this hierarchical supremacy is to be evaluated.

For example, someone cannot disregard that jurisprudential unity is achieved in domestic law through the existence of supreme or high courts whose decisions bind either de jure or de facto lower courts, depending whether a particular judicial system belongs to the common law or continental law tradition. Continental law holds another feature that can be useful for the international judicial scheme. While in common law countries, the Supreme Court can adjudicate both cases of civil and penal as well as administrative law, in continental law, there are two separate superior courts: One hearing civil/penal cases and the other exercising judicial review as a court of first instance against government decisions. Quite interestingly, these two superior courts tend to act independently one from the other, behaving like there are two distinct channels of justice distribution that can both reach the highest level of judicial pronouncement.

In that sense, the same could also be true in the international field, with the ICJ being the ultimate superior court for civil/administrative matters and the ICC for criminal issues. ${ }^{67}$ The ICJ already stands as the superior court. Its decisions are cited by other courts and tribunals and even its advisory opinions are often treated as the pronouncement of law. ${ }^{68}$ In these realms, it can be easily perceived as sitting on top of the judicial pyramid, minus the formal binding effect of its pronouncements. In fact, other courts and tribunals can eventually deviate from the ICJ's rulings. For example, in the Tadic case, the ICTY decided to take a different stance on the level of control required in order for non-state actions to be attributed to a state. ${ }^{69}$

While the Rome Statute explicitly provides for the ICC to take the cases once domestic fora prove unwilling or unable to do so, there is no explicit provision for such an ICJ jurisdiction. It could be argued that this competence derives from the Court's role as the international community's principal judicial organ and from adherence to human rights as enshrined in Article 55 of the UN Charter. This scheme-while not necessarily arguing for the creation of a separate international human rights court-does argue that eventually the pronouncement on human rights issues on a universal level is necessary in cases in which the instruments are universal. Moreover, this interpretational task must be undertaken by the ICJ instead of regional courts, whose jurisdiction would further blur the international jurisdictional landscape. ${ }^{70}$

Two arguments could strike against international jurisdictional constitutionalism. First, many international courts and tribunals are specific rationae loci or materiae. On the one hand, the International Criminal Tribunals for the former Yugoslavia or Rwanda refer only to crimes committed in these countries. The same is also true for the Special Court on Sierra Leone. On the other hand, the Special Tribunal for Lebanon has been instituted in order to focus on one specific act: The assassination of Lebanon's former prime minister. These courts do not have general jurisdiction on all international law issues as the ICJ does. In that sense, they are substantially different and cannot form the lower instances of a pyramid where the ICJ sits at the top.

Accordingly, it could be argued that these courts and tribunals are indeed international because they have been formed by the international community through a multilateral treaty or through the powers a multilateral treaty like the UN Charter confers to the SC. On the contrary, these courts and tribunals should be deemed as regional, either thematically-covering a certain spectrum of issues ${ }^{71}$ or locally-covering a specific region. In that sense, they do not fall within the legal pyramid the ICJ forms. They have an autonomous presence, meant to be harmonized through internal dialogue between these courts or the principle of comity between them and their

\footnotetext{
${ }^{66}$ On this see art. 92 of the UN Charter.

${ }^{67}$ See also Romano, acknowledging the two distinct criminal and civil legs of the international legal order and discussing whether the UN Human Rights Committee could form the civil leg in this structure if it issued binding decisions and not just nonbinding observations. (C Romano, 'Can you Hear Me Now? The Case For Extending the International Judicial Network' (2009) 10 Chi. J. Int'l. L. 233, 268)

${ }^{68}$ M Aljaghoub, The Advisory Function of the International Court of Justice 1946-2005 (2006) 116-117

${ }^{69}$ Prosecutor v. Tadić, Case No. IT-94-1-A, Judgment, para.120, July 15, 1999

${ }^{70}$ K. Alter, L. Helfer \& J McAllister, A New International Human Rights Court for West Africa: The ECOWAS Community Court of Justice, (2013) 107 Am. J. Int'l. L. 737, 739 (providing examples also of regional courts with human rights jurisdiction.)

${ }^{71}$ This would be the case for example with ITLOS or the WTO Appellate Body.
} 
domestic counterparts. ${ }^{72}$ They act as judicial isles, unconnected to each other. This means that these courts and tribunals can actually interpret an international rule that has a global, cosmopolitan effect, but cannot proceed to its annulment. Resorting again to domestic constitutional law, these courts can exercise judicial review on the constitutionality of a principle, but unlike a Constitutional Court, they cannot annul it.

Under this lens, domestic courts should be viewed as the judicial partners of the ICJ in this pyramid structure. Domestic courts are meant to counteract with the ICJ, incorporating its pronouncements in their decisions.

At the same time, domestic courts also interact and authentically interpret international law dicta. ${ }^{73}$ In order for international jurisdictional constitutionalism to be maintained, it is important that these domestic courts' interpretations are always bound to the pronouncement of the ICJ or the ICC. Thus, decisions are ultimately checked by standards set by international law. The supplementary role of the emerging international judicial network vis $a$ vis domestic courts ${ }^{74}$ includes the ICJ and the ICC acting as courts of last resort in cases to which domestic courts are unwilling or unable to distribute justice or in which local remedies have been exhausted. ${ }^{75}$

On one hand, the ICC can act as Cour de Cassation, in cases where regional criminal courts constitute courts of appeal for domestic courts. Indeed, this has also been the pattern proposed by some of the advocates of the creation of an international criminal court for Africa ${ }^{76}$ and this is also the structure the African Court's draft Statute seems to envision by stipulating that the Court is also vested with an original and appellate jurisdiction in criminal cases. ${ }^{77}$

On the other hand, as exemplified in the Al Dulimi case, the role jurisdictional constitutionalism asks the ICJ to fill is more complex: The Court is to interpret human rights norms, thus dealing inevitably with certain facts. Yet, this judicial review refers principally to the validity and extension of a human rights norm and not to its implementation in a specific case..$^{78} \mathrm{In}$ that respect, the Court remains a fact-finding court, acting more as a Cour de Cassation or a Constitutional Court, clarifying in a cosmopolitan interpretational manner the legal dicta of certain Resolutions or the relationship between the various fields of international law. ${ }^{79}$

Regional judicial bodies lack this capacity. As such, it proves inept to efficiently interpret or encompass all the global parameters necessary for the correct construe of instruments of legal cosmopolitanism. In other words, cosmopolitan texts-meant to impose cohesive and uniform duties for all states-should be judicially reviewed by organs that can similarly impose uniform and global compliance. Because each continent holds different values and legal traditions, a SC Resolution will be interpreted differently in Europe by the ECHR than in America

\footnotetext{
${ }^{72}$ As such, see the draft Statute of the African Court of Justice and Human Rights stipulating that "the Court shall be entitled to seek the co-operation or assistance of regional or international courts, non-State Parties or co-operating partners of the African Union and may conclude agreements for that purpose." For more see Don Deya, Is the African Court Worth the Wait?, March 6, 2012, Open Society Initiative for Southern Africa available at http://www.osisa.org/openspace/regional/african-court-worth-wait

${ }^{73}$ D Hovell, 'A Dialogue Model: The Role of the Domestic Judge in Security Council Decision-Making' (2013) 26 Leiden J. Int'I. L. 579,580

${ }^{74}$ C Romano, Can you Hear Me Now? The Case For Extending the International Judicial Network' (2009) 10 Chi. J. Int'l. L. 233,239

75 Ibid.

${ }^{76}$ Walter Menya, African Leaders to Discuss Regional War Crimes Court, Institute for War \& Peace Reporting, Jan. 23, 2013 available at http://iwpr.net/report-news/african-leaders-discuss-regional-war-crimes-court (citing Gershom Otachi, an attorney representing African defendants before international and regional criminal courts and tribunals and Charles Kanjama of the Kenyan Law Society)

77 Draft Protocol on Amendments to the Protocol on the Statute of the African Court of Justice and Human and Peoples' Rights, Meeting of Government Experts and Ministers of Justice /Attorneys General on Legal Matters, May 7-11 and 14-15 2012, Addis Ababa, Exp/Min/IV/Rev.7, p.3, art.1

${ }^{78}$ See for example Rosalyn Higgins noting that while until recently the Court was a Court of sovereign States, it has been recently become also a court concerned with human rights. ( R Higgins, Human Rights in the International Court of Justice (2007) 20 Leiden J. Int'l. L. 745, 746. )For the fact that the ICJ cannot adequately serve as a human rights court dealing with complaints against individual human rights violations due to its State to State and not State-individual structure see J Crook, The International Court of Justice and Human Rights (2004) 1 NW. U. J. Int'I. Hum. Rts. 2 [add pincite].

${ }^{79}$ For the fact that the Court has done this regarding the relationship between international humanitarian law and human rights law through the introduction of the lex specialis principle see Advisory Opinion on the Legality of the Use or Threat of Nuclear Weapons, ICJ Rep. 1996, para. 26. For the fact that sometimes the award of preponderance of a field over another is not possible see S. Solomon, The Justiciability of International Disputes (2009) 125
} 
by the Inter-American Court of Human Rights. This judicial relativity ultimately works to the detriment of individuals residing in geographical units that have not developed an entrenched human rights tradition.

This does not mean that in cases like Al Dulimi judicial regionalism has to remain silent. Nevertheless, the solution is not to strike down a norm such as a SC Resolution. Rather, international jurisdictional constitutionalism should favor the construction of a mechanism similar to the one existing in the realms of the European legal order, where domestic courts cannot annul a European regulation, but have to stall proceedings and send an inquiry to the European Court of Justice on the interpretation of a piece of European legislation. ${ }^{80}$ As such, the European Court of Justice becomes the ultimate keeper and arbiter of the European legal order. De lege ferenda, the transplantation of the European law procedure already suggested for other domestic legal orders, ${ }^{81}$ should not be precluded in the international field where judicial regional bodies could similarly stall proceedings and address a question to the ICJ regarding the legality of an SC Resolution once human rights issues emerge.

\section{Judicial Regionalism and International Thematic Judicial Constitutionalism: Quo Vadis?}

While the previous section mapped the doctrinal treatment of international jurisdictional thematic constitutionalism, it is true that the challenges judicial regionalism addresses are also present. Two choices are left before him: Either keep its distinct thematic and peripheral role or try to enter the international judicial pyramid by claiming the role domestic courts now occupy. While the first may be monotonous, the second is tenuous. Yet, it is feasible.

In some instances, the civil and criminal jurisdictions may unite in some courts whose jurisdiction spans over a wide range of civil and criminal matters. ${ }^{82}$ But such function of regional judicial bodies requires a complete renegotiation of certain precepts. Without any encompassing discussion and preparation, any such attempts may actually harm punitive cosmopolitanism.

Any assumption that regional judicial bodies can act on an autonomous level is ultimately doomed by punitive cosmopolitanism and the promotion of international justice. ${ }^{83}$ This is particularly true when taking into account that international criminal jurisdiction was enacted in African regional courts as a response to the ICC's reluctance to halt proceedings against African leaders. ${ }^{84}$ Norms of hierarchy have to be established in order for individuals and groups not to start engaging in forum shopping, particularly in criminal matters involving prosecutions of individuals. ${ }^{85}$

The need for normative hierarchy is palpably stressed in cases like that of Al Dulimi, which call for a redefinition of the role of judicial regionalism in cases of non-discretionary administrative measures. In this respect, resort to the European Union law model could be useful.

\footnotetext{
${ }^{80}$ M Broberg \& N Fenger, Preliminary References to the European Court of Justice (2010) 14

${ }^{81}$ C Chan, 'Implementing China and Hong Kong's Preliminary Reference System: Transposability of Article 267 TFEU Principles' University of Hong Kong Faculty of Law Research Paper available at http://papers.ssrn.com/sol3/papers.cfm?abstract_id=2365246

${ }^{82}$ Christabel Ligami, EACJ to Handle Criminal Offences, The East African, Dec. 7, 2013 available at http://www.theeastafrican.co.ke/news/EACJ-to-handle-criminal-offences/-/2558/2103006/-/bkbsq5/-/index.html
}

${ }^{83}$ For the stance that the African Court of Justice and Human Rights with criminal jurisdiction can co-exist with the ICJ or the ICC see Don Deya, Is the African Court Worth the Wait?, March 6, 2012, Open Society Initiative for Southern Africa available at http://www.osisa.org/openspace/regional/african-court-worth-wait

\footnotetext{
${ }^{84}$ Criminal jurisdiction of the East African Court of Justice was established after the failed request for proceedings for the four suspects of the post-election violence in Kenya to be transferred from the ICC to the East African Court. On this see Kai Ambos, Introduction in Power and Prosecution: Challenges and Opportunities for International Criminal Justice in Sub-Saharan Africa, Kai Ambos \& Ottilia Maunganidze (eds., 2012) 11

${ }^{85}$ For examples of such forum shopping in universal jurisdiction cases see M Inazumi, Universal Jurisdiction in Modern International Law: Expansion of National Jurisdiction for Prosecuting Serious Crimes Under International Law (2005) 203
} 
Under Article 263 of the TFEU, the European Court of Justice (ECJ) exercises judicial review over the Commission's decisions, substituting its discretion for that of the Commission. ${ }^{86}$ Moreover, in cases where the deciding body enjoys reduced discretion, the infringement of Community law may be sufficient for the establishment of a serious breach, enough to incur non-contractual liability. ${ }^{87}$ Failure to accord appropriate procedural rights to certain individuals before taking a decision is among the errors that could lead to EU liability. ${ }^{88}$

Transplanting the legal-executive dialogue from the European to the national level, it could be similarly argued that the ECHR could pronounce the liability of the Swiss government for not guaranteeing Al-Dulimi's procedural rights. Given the non-automatic preponderance of human rights law, such a mutatis mutandis resort to the European model would help doctrinally explain the need for such human rights parameters to constitute the yardstick for the justiciability of the matter before the ECHR as well as before domestic courts. ${ }^{89}$ Moreover, this pattern aligns with views that on a teleological basis the SC Resolutions should be harmonized with human rights law $^{90}$ and ultimately with international thematic constitutionalism and the prominent position the latter awards to the right to dignity.

\section{E. Conclusion}

Analyzing cases of judicial regionalism in two diverse geopolitical entities, Africa and Europe, this Article demonstrates how regional efforts can thwart the UN Security Council's punitive cosmopolitanism, namely attempts to impose common global institutions or rules for the denouncement of certain behaviors.

In principal, the fervor with which regional bodies aspire to intervene should be applauded. At the same time, judicial regionalism can significantly undermine efforts to impose order in the international legal landscape through its constitutionalization. In these realms, the arrangement of the powers and competencies among international courts and tribunals as well as between the latter and domestic courts should be one of the priorities of international law. Non-coordinated or regional judicial initiatives like these undertaken by the African Union or embedded in the Al-Dulimi judgment do not help movement in this direction. Ultimately and echoing the two pillars of justice and peace, international judiciary should learn to see itself crowned by the ICC and ICJ respectively.

\footnotetext{
${ }^{86}$ J. C. Laguna de Paz, Understanding the Limits of Judicial Review in European Competition Law (2013) J. Antitrust Enforcement 1, 7-8

${ }^{87}$ Afrikanische Frucht Companie and Internationale Fruchtimportgesellschaft Weichert v. Council and Commission, Joint Cases T-64/01 \& T-65/01, Judgment of the Court of First Instance (Fifth Chamber) Feb. 10, 2004, para.71; Comafrica and Dole Fresh Fruit Europe v. Commission, T-139/01, Judgment of the Court of First Instance, Feb. 3, 2005, para.142; H. Hofmann, G. Rowe \& A. Turk, Administrative Law and Policy of the European Union (OUP, 2011) 889

${ }^{88}$ P. Craig, EU Administrative Law (OUP, $2^{\text {nd }}$ ed. 2012) 690

${ }^{89}$ See for example Tzanakopoulos, noting that Canadian domestic courts used jus cogens as the yardstick for measuring the legality of a UN act and approving the domestic courts' intervention in cases of violation of the hard core of basic rights with universal radiance, such as the right to a fair trial. A. Tzanakopoulos, United Nations Sanctions in Domestic Courts: From Interpretation to Defiance in Abdelrazik v. Canada (2010) 8 JICJ 249, 258, 263-64

${ }^{90} \mathrm{~V}$ Gowlland-Debbas, The Security Council as Enforcer of Human Rights in Securing Human Rights? Achievements and Challenges of the UN Security Council (B Fassbender ed., 2011) 69-70
} 